\title{
MIGRATION OF Y-BEARING HUMAN SPERMATOZOA IN CERVICAL MUCUS
}

\author{
W. ROHDE, T. PORSTMANN AND G. DÖRNER \\ Institute of Experimental Endocrinology, Humboldt-University (Charité), \\ 104 Berlin, GDR
}

(Received 13th November 1972)

Summary. Migration of human spermatozoa in cervical mucus obtained from women shortly before mid-cycle was studied, using an in-vitro method for horizontal sperm penetration. The results indicate that a small number of $\mathrm{Y}$-bearing spermatozoa form the frontal zone during active migration.

A deviation of sex ratio depending on the time of conception during the menstrual cycle has been postulated on the basis of clinical observations and, more recently, of differential migration of $\mathrm{X}$ - and $\mathrm{Y}$-bearing spermatozoa (Fürst, 1886; Pryll, 1916; Siegel, 1916; Asdell, 1927; Kleegman, 1954; Benendo, 1970; Guerrero, 1970). The introduction of a fluorescent staining technique for the identification of $Y$ chromosomes in interphase nuclei (Caspersson, Zech, Johansson, Lindsten \& Hultén, 1970; Pearson, Bobrow \& Vosa, 1970) made possible the distinction of X-and Y-bearing human spermatozoa (Barlow \& Vosa, 1970). In a re-examination of the theory of Shettles (1970) that the variation of $\mathrm{pH}$ in cervical mucus during the menstrual cycle influences the migration of X and Y spermatozoa, Diasio \& Glass (1971) were unable to demonstrate a significant change in the ratio of spermatozoa with fluorescent Y-bodies on the basis of migration through Tyrode's solutions of varying $\mathrm{pH}$.

The present investigation was undertaken to study the migration of Y-bearing spermatozoa in the cervical mucus and to examine the suitability of this natural medium for the separation of X-and Y-bearing spermatozoa.

Samples of cervical mucus were obtained from ten healthy women (26 to 34 years old) shortly before mid-cycle. The volume, viscosity, spinnbarkeit and ferning characteristics of each sample were recorded. Two donors provided freshly ejaculated 'normal' semen samples, which were allowed to liquefy for 10 to $15 \mathrm{~min}$ at $37^{\circ} \mathrm{C}$. All materials were incubated at $37^{\circ} \mathrm{C}$ up to the time of the experiments.

A special slide method was developed for horizontal sperm penetration in cervical mucus, which made it possible to arrest migration and to fix and stain the specific migration pattern (Porstmann, Rohde \& Traut, 1972). A channel ( $1 \mathrm{~mm}$ wide $\times 1 \mathrm{~mm}$ deep $\times 70 \mathrm{~mm}$ long) was filled with fresh cervical mucus for a distance of $60 \mathrm{~mm}$ and a drop of semen $(0.025 \mathrm{ml})$ was immediately applied to the end of this horizontal mucus column ('start position'). Sperm penetration of the mucus was allowed to proceed at $37^{\circ} \mathrm{C}$ for $45 \mathrm{~min}$ in a moist chamber. 
After drying, the material was fixed, stained in $0.5 \%$ quinacrine dihydrochloride and analysed by fluorescence microscopy as described by Rohde, Porstmann, Zillmann \& Dörner (1972). The slides were scanned systematically from the start position to the zone of the most quickly migrating spermatozoa ('frontal zone') for spermatozoa with Y-bodies. As a control, 200 to 300 successive spermatozoa were counted in samples of semen and of a mixture of semen and cervical mucus.

The preliminary results of seven experiments investigating the active migration of Y-bearing spermatozoa in cervical mucus from women shortly before mid-cycle are summarized in Table 1 . A highly significant increase of $\mathrm{Y}$-bearing

Table 1. Spermatozoa showing Y-fluorescence before and after migration in cervical mucus obtained from women shortly before mid-cycle

\begin{tabular}{l|c|c}
\hline & Before migration & After migration \\
\hline Range & 25 to $40 \%$ & 50 to $71 \%^{*}$ \\
Mean \pm S.D. & $34.3 \pm 5.7^{*}$ & $58.3 \pm 8 \cdot 8^{\dagger}$ \\
\hline
\end{tabular}

No. of experiments $=7$.

* Counted in the frontal zone.

+ Increase highly significant $(P<0.001)$.

spermatozoa in the frontal zone of sperm migration was observed. Examination of the percentage of Y-bodies in spermatozoa from the start position up to the frontal zone showed that the percentage of spermatozoa with Y-bodies was significantly changed only in the frontal zone (K.R. and L.G. in Text-fig. 1). In three further experiments, the migration of spermatozoa progressed up to the end of the slide and the frontal zone was diluted with the succeeding spermatozoa (P.G. in Text-fig. 1), so that the proportion of Y-bearing spermatozoa showed a small increase only.

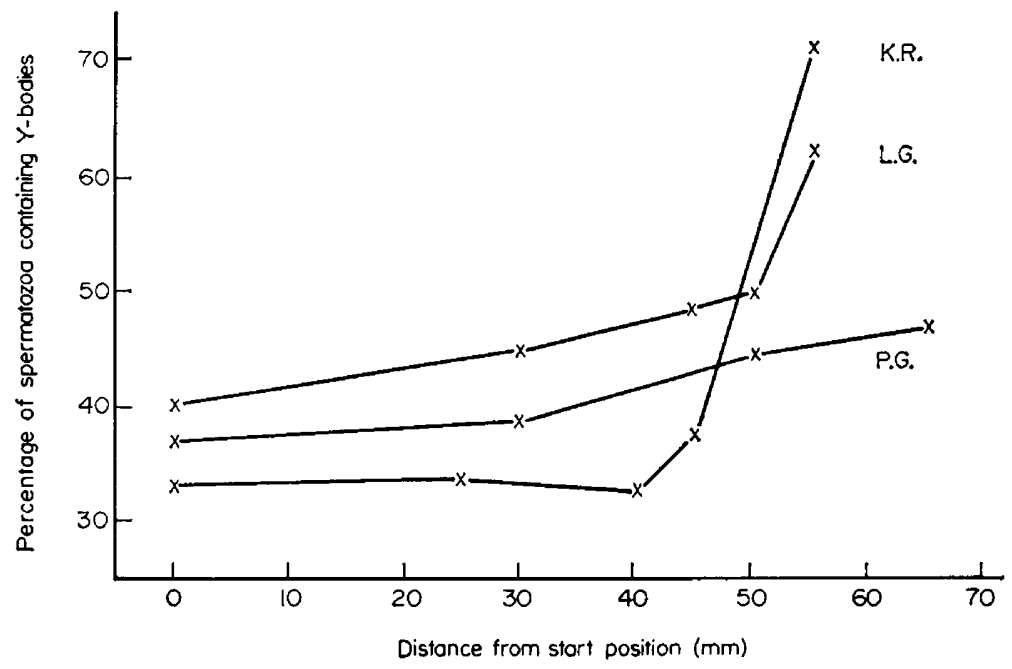

TexT-FIG. 1. Percentage of human spermatozoa containing demonstrable Y-bodies evaluated at different migration points in three experiments, using samples of cervical mucus taken from three women (K.R., L.G. and P.G.) shortly before mid-cycle. 
In three other experiments with cervical mucus from other stages of the menstrual cycle, little or no penetration by spermatozoa was found.

No significant difference was seen between the percentage of Y-bodies in spermatozoa at the start position in the migration experiments and in smears of semen alone. In order to evaluate a possible influence of cervical mucus on the percentage of visible Y-bodies in Y-bearing spermatozoa as seen after mild digestion of trypsin (Rohde et al., 1972), mixtures of spermatozoa and cervical mucus were analysed. No significant change was found by comparison with the percentage of Y-bodies in the spermatozoa in semen alone.

Since not all the Y-bearing spermatozoa can be demonstrated by fluorescence microscopy, it is possible that in some of the migration experiments, nearly $100 \%$ of Y-bearing spermatozoa were actually present in the frontal zone. In vivo, these faster Y-bearing spermatozoa might reach the ovum first, when it is available for fertilization, although the passage of the spermatozoa through the uterus and oviduct have also to be taken into consideration.

The absolute number of spermatozoa in the frontal zone was very small. On average, twenty-two cells only were counted in our experiments. This in-vitro method appears, therefore, to be unsuitable for sex control. Further studies with other techniques for separation of the two populations of spermatozoa are in progress.

\section{REFERENGES}

Asdell, S. A. (1927) Time of conception and ovulation in relation to the menstrual cycle. 7 . Am. med. Ass. 89, 509.

Barlow, P. \& Vosa, G. G. (1970) The Y chromosome in human spermatozoa. Nature, Lond. 226, 961.

BENENDO, F. (1970) The problem of sex determination in the light of own investigations. Endokr. pol. $21,265$.

Caspersson, T., Zech, L., Johansson, C., Lindsten, J. \& Hultén, M. (1970) Fluorescent staining of heteropycnotic chromosome regions in human interphase nuclei. Expl Cell. Res. 61, 472.

Diasio, R. B. \& Glass, R. H. (1971) Effects of $\mathrm{pH}$ on the migration of $\mathrm{X}$ and Y sperm. Fert. Steril. 22, 303.

Fürst, G. (1886) Knabenüberschuss nach Conception zur Zeit der postmenstruellen Anämie. Arch. Gynaek. 28, 14.

GUERrERo, R. (1970) Sex ratio: a statistical association with the type and time of insemination in the menstrual cycle. Int. 7. Fert. 15, 221.

Kleggman, S. (1954) Therapeutic donor insemination. Fert. Steril. 5, 7.

Pearson, P. L., Bobrow, M. \& Vosa, G. G. (1970) Technique for identifying Y chromosomes in human interphase nuclei. Nature, Lond. 226, 78.

Porstmann, T., Rohde, W. \& Traut, W. (1972) Vorrichtung zur Bestimmung der horizontalen linearen Spermienwanderung mit anschliessender Fixierungs- und Färbemöglichkeit. Ztschr. med. Labortech. 13, 299.

PrYLL, W. (1916) Kohabitationstermin und Kindgeschlecht. Münch. med. Wschr. 63, 1579.

Rohde, W., Porstmann, T., Zillmann, R. \& Dörner, G. (1972) Zum fluoreszenzmikroskopischen Nachweis des Y-Chromosoms in unbehandelten und trypsinbehandelten menschlichen Spermien. Acta biol. med. germ. 28, 189.

SHETtLes, L. B. (1970) Factors influencing sex ratios. Int. F. Gynec. Obstet. 8, 643.

SIEGEL, P. W. (1916) Bedeutung des Kohabitationstermines für die Befruchtungsfähigkeit der Frau und für Geschlechtsbildung des Kindes. Münch. med. Wschr. 63, 748. 